\title{
PHOSPHORUS AND HEAVY METAL CONTENTS IN SMALL-SCALE COMPOSTING AREAS
}

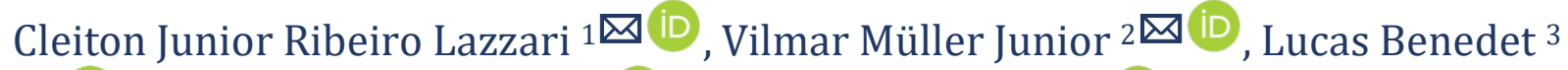

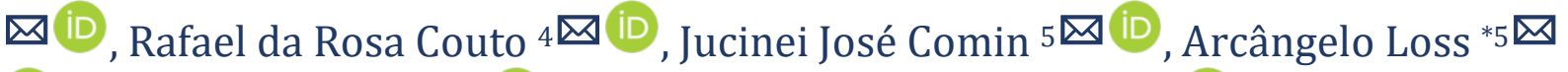

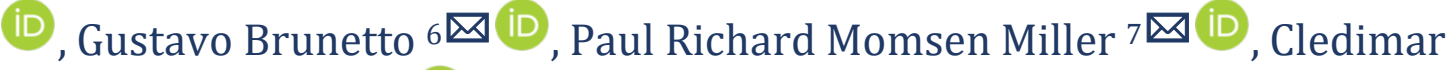
Rogério Lourenzi 5 (iD

1 Programa de Pós-Graduação em Ciência do Solo, Universidade do Estado de Santa Catarina, Lages, Santa Catarina, Brasil

2 Programa de Pós-Graduação em Engenharia Ambiental, Universidade Federal de Santa Catarina, Florianópolis, Santa Catarina, Brasil

${ }^{3}$ Programa de Pós-Graduação em Ciência do Solo, Universidade Federal de Lavras, Lavras, Minas Gerais, Brasil

${ }^{4}$ Instituo Federal Catarinense, Rio do Sul, Santa Catarina, Brasil

5 Programa de Pós-Graduação em Agroecossistemas, Universidade Federal de Santa Catarina, Florianópolis, Brasil

${ }^{6}$ Programa de Pós-Graduação em Ciência do Solo, Universidade Federal de Santa Maria, Santa Maria, Rio Grande do Sul, Brasil

7 Departamento de Engenharia Rural, Universidade Federal de Santa Catarina, Florianópolis, Brasil

DOI: https://doi.org/10.29121/granthaalayah.v8.i8.2020.730

Article Type: Research Article

Article Citation: Cleiton Junior Ribeiro Lazzari, Vilmar Müller Junior, Lucas Benedet, Rafael da Rosa Couto, Jucinei José Comin, Arcângelo Loss, Gustavo Brunetto, Paul Richard Momsen Miller, and Cledimar Rogério Lourenzi. (2020). PHOSPHORUS AND HEAVY METAL CONTENTS IN SMALL-SCALE COMPOSTING AREAS. International Journal of Research -GRANTHAALAYAH, 8(8), 1-14. https://doi.org/10.29121/granthaalayah.v8.i8.2020.730

Received Date: 13 July 2020

Accepted Date: 18 August 2020

Keywords:

Food Waste

Organic Compost

Leachate

Environmental Contamination

\section{ABSTRACT}

Composting is an important tool for recycling and proper disposal of organic waste. However, in small-scale composting, where total soil sealing and leachate collection is not carried out, elements such as $\mathrm{P}, \mathrm{Cu}, \mathrm{Zn}, \mathrm{Cd}, \mathrm{Cr}, \mathrm{Ni}$ and $\mathrm{Pb}$ may accumulate in soil. This study aimed to assess phosphorus and heavy metal contents in soils of areas used for small-scale food waste composting. In order to do this, we sampled soil depths of 0-5, 5-10, 10-20, 20-30 
and 30-40 cm of four areas with composting times of 16, 12, 7 and 1 year, in addition to four reference areas. All the study areas are located in the city of Florianópolis, Santa Catarina state, Brazil. We determined available $\mathrm{P}, \mathrm{Cu}$ and $\mathrm{Zn}$ contents and total $\mathrm{Cu}, \mathrm{Zn}, \mathrm{Cd}, \mathrm{Cr}, \mathrm{Ni}$ and $\mathrm{Pb}$ contents in the soil samples. We found that the production of organic compost directly on the soil generally promoted increases in available $\mathrm{P}$ contents, which were above acceptable environmental limits, especially at the uppermost soil layers. Still, the presence of $\mathrm{Cu}, \mathrm{Zn}, \mathrm{Cd}, \mathrm{Cr}, \mathrm{Ni}$ and $\mathrm{Pb}$ was not an environmental liability in the composting areas, as the contents found were below those recommended by legislation.

\section{INTRODUCTION}

Waste production in urban areas has increased significantly in recent decades, with emphasis on food waste, either due to improper handling during processing or wastage in restaurants and households. A suitable alternative for these wastes is composting, which is a biological process of decomposition and stabilization of organic substrates under controlled thermophilic and aerobic conditions (Bernal, 2009; Cadis \& Henkes, 2014). Composting promotes oxidation and, consequently, mineralization and partial humification of waste organic matter. This results in a stabilized, pathogen-free, non-toxic product to plants with important chemical properties such as high $\mathrm{pH}$ and significant nutrient contents, which can be used for soil conditioning and plant nutrition (Chowdhury et al., 2013; Martínez-Blanco et al., 2013).

There is typically leachate production during the composting process. The amount produced is dependent on the type of material used to make the compost, the size of the pile and the volume of precipitation on the compost pile. The leachate from the pile transports chemical elements from the composting material. The elements and their concentrations vary. $\mathrm{P}, \mathrm{Cu}$ and $\mathrm{Zn}$ contents of 1.2 to $32.7,0.3$ to 3.0 and 1.0 to $5.0 \mathrm{mg} \mathrm{L}^{-1}$ have been found in 100 to $800 \mathrm{~L}$ of leachate per $\mathrm{m}^{2}$, obtained from piles with $460 \mathrm{~kg}$ of dry matter per $\mathrm{m}^{3}$, respectively (Christensen, 1984; Christensen \& Tjell, 1984; Chatterjee et al., 2013).

In Brazil, in composting systems classified as small-scale (Brasil et al., 2017), piles are usually made directly on the soil and leachate from the compost pile is not collected. Furthermore, the soil under the pile is not fully sealed. When there is soil sealing, it is done with compacted clay, but it does not prevent leachate percolation into soil. This may result in the accumulation of nutrients and heavy metals in soil. In a literature review, Hargreaves et al. (2008) found an increase in available contents of $\mathrm{P}, \mathrm{Cu}$ and $\mathrm{Zn}$ in soil with the addition of urban solid waste compost. However, these authors also highlighted the increase in total contents of $\mathrm{Cd}, \mathrm{Cr}, \mathrm{Ni}$ and $\mathrm{Pb}$. Still, in a study with annual applications of municipal solid waste compost (40 and $80 \mathrm{t} \mathrm{ha}^{-1}$ ) in a wheat-growing area for four years, Ayari et al. (2010) found increases in total $\mathrm{Cu}, \mathrm{Zn}, \mathrm{Cd}, \mathrm{Cr}, \mathrm{Ni}$ and $\mathrm{Pb}$ contents at a depth of 0-20 cm.

The increase in available or total contents of $\mathrm{P}, \mathrm{Cu}, \mathrm{Zn}, \mathrm{Cd}, \mathrm{Cr}, \mathrm{Ni}$ and $\mathrm{Pb}$ in soil, as observed in several studies using organic sources (Ceretta et al., 2010a; Ayari et al., 2010; Guo \& Li, 2012; Lourenzi et al., 2014; Couto et al., 2015ab, Lourenzi et al., 2016), may cause imbalances in the environment such as eutrophication resulting from increased $\mathrm{P}$ content in water (Smith et al., 2006). Also, the presence of high $\mathrm{Cu}, \mathrm{Zn}, \mathrm{Ni}, \mathrm{Cd}, \mathrm{Cr}$ and $\mathrm{Pb}$ contents may even result in phytotoxicity and hinder plant growth (Kopittke et al., 2010). In this sense, in a literature review on heavy metal phytotoxicity in plants, Kopittke et al. (2010) observed a general response behavior of plants to the presence of heavy metals in the solution. The degree of toxicity was as follows $\mathrm{Pb}>\mathrm{Cu}>\mathrm{Cd}>\mathrm{Ni} \approx \mathrm{Zn}$, with average toxic concentrations (in $\mu \mathrm{M}$ ) of $0.30(\mathrm{~Pb}) ; 2.0(\mathrm{Cu}) ; 5.0(\mathrm{Cd}) ; 19.0(\mathrm{Ni})$ and $25.0(\mathrm{Zn})$. $\mathrm{Cu}, \mathrm{Zn}$ and $\mathrm{Cr}$ are considered essential elements for humans, while $\mathrm{Cd}, \mathrm{Ni}$ and $\mathrm{Pb}$ are non-essential elements. However, all of these elements can cause toxicity in humans. Some symptoms of heavy metal poisoning are hyperglycemia and liver glucose (Cu); tissue injury and anemia (Zn); pneumonia, gastroenteritis, cardiomyopathy, and cancer (Cd); skin lesion, pulmonary edema, and lung cancer (Cr); neurological effects and lung cancer (Ni); nervous system disorders and intestinal irritation (Pb) (Kabata-Pendias \& Mukherjee, 2007). Therefore, it is important to assess the contents of these elements in soil, as they can be absorbed by plants (Ji et al., 2018) or reach water sources (Rajeshkumar et al., 2018), and cause health problems to human beings.

Thus, this study aimed to assess phosphorus and heavy metal contents in soils of areas used for small-scale food waste composting in the city of Florianópolis, Santa Catarina state, Brazil. 
Cleiton Junior Ribeiro Lazzari, Vilmar Müller Junior, Lucas Benedet, Rafael da Rosa Couto, Jucinei José Comin, Arcângelo Loss, Gustavo Brunetto, Paul Richard Momsen Miller, and Cledimar Rogério Lourenzi

\section{MATERIAL AND METHODS}

\subsection{DESCRIPTION OF THE STUDY SITE AND COMPOSTING PROCESS}

Eight areas located in the city of Florianópolis, state of Santa Catarina, Brazil, were selected for this study (Table 1). Four of which had a history of small-scale composting (Brasil, 2017) and four areas adjacent to the composting sites used as reference areas (Table 1). However, the composting and reference areas were not set up on natural soils of the region, but rather on landfill sites with soil from other regions or with mixed clayey soil and construction waste. Each area assessed in this study was prepared differently for the making of the compost piles. Areas $1 \mathrm{C}$ and $1 \mathrm{R}$ were prepared with construction waste (inert material) at deeper layers and material with higher sand content at surface layers. On the other hand, areas 2C and 2R were made up of construction waste and clayey soil. Areas 3C and 3R were located over a dumping ground set up in 1990. Area 3C contained material from construction waste and clayey soil, while 3R was composed of a landfill with soil from adjacent mangrove areas. Lastly, 4C was located in an area previously used for shrimp ponds, which was landfilled with construction waste and clayey soil, while 4R (similar to 3R) was composed of soil from adjacent mangrove areas.

Table 1: Selected areas, location, coordinates and composting time.

\begin{tabular}{|c|c|c|c|}
\hline Area & Location & Coordinates & Composting time \\
\hline 1C & UFSC & $27^{\circ} 35^{\prime} 50.35^{\prime \prime} \mathrm{S} 48^{\circ} 30^{\prime} 55.12^{\prime \prime} \mathrm{W}$ & 12 years \\
\cline { 1 - 1 } 1R & UFSC & & Reference \\
\hline 2C & UFSC & $27^{\circ} 34^{\prime} 43.20^{\prime \prime} \mathrm{S} 48^{\circ} 30^{\prime} 19.34^{\prime \prime} \mathrm{W}$ & 16 years \\
2R & UFSC & & Reference \\
\hline 3C & COMCAP & $27^{\circ} 35^{\prime} 0.13^{\prime \prime} \mathrm{S} 48^{\circ} 30^{\prime} 51.49^{\prime \prime} \mathrm{W}$ & 7 years \\
\cline { 1 - 1 } 3R & COMCAP & & Reference \\
\hline 4C & UFSC & \multirow{2}{*}{$27^{\circ} 35^{\prime} 6.20^{\prime \prime} \mathrm{S} 48^{\circ} 30^{\prime} 32.29^{\prime \prime} \mathrm{W}$} & 1 year \\
\hline 4R & UFSC & & Reference \\
\hline
\end{tabular}

UFSC: Universidade Federal de Santa Catarina; COMCAP: Companhia Melhoramentos da Capital; The letters "C" and " $R$ " refer to composting and reference areas, respectively.

All the composting areas were outdoors, with no protection from precipitation and no leachate collection. The compost piles were built with food waste (material with low $\mathrm{C} / \mathrm{N}$ ratio), including vegetables, fruits, grains, meat and processed products (cooked or fresh) from restaurants, cafeterias, supermarkets, etc., as well as shavings, sawdust or pruned material from urban trees (material with high $\mathrm{C} / \mathrm{N}$ ratio).

Approximately 700 to 1000 tons of waste per year was added to the composting areas. The waste was arranged in piles of variable length, width of 1.5-2.0 m and height of $1.3-1.5 \mathrm{~m}$ when built manually, and $3.0 \mathrm{~m}$ wide and tall when built with the help of implements (Inácio \& Miller, 2009; Maestri, 2010). Each pile holds approximately 1.33 tons of material per $\mathrm{m}^{3}$. As there is no set position within the area, each new pile was built at a different location, which means that the whole area had a compost pile on its surface at some point.

The composting method used was static piles with passive aeration, known as the UFSC method (Inácio \& Miller, 2009). The piles are not turned, and they are built using at least $1 / 3$ of structural material (material with high $\mathrm{C} / \mathrm{N}$ ratio). Food waste was added to the piles 2 to 3 times a week, until the desired size was reached. Every time new material was added, it was mixed with the material from the upper part of the pile. The piles were built with a 30 to $50 \mathrm{~cm}$ layer of structural material (sawdust) followed by a 20 to $25 \mathrm{~cm}$ layer of food waste. A layer of grass clippings of approximately $25 \mathrm{~cm}$ was added to the sides and surface to protect the piles. The composting process lasted 90 to 180 days from building the piles until the final compost was obtained. This process was carried out similarly in all the composting areas. It is important to note that in areas $1 \mathrm{C}$ and $3 \mathrm{C}$, the soil was scraped at a depth of around 10 $\mathrm{cm}$ when the compost pile was removed, and a new layer of soil was added to these areas prior to the installation of new piles. 


\subsection{SOIL COLLECTION}

In January 2014 (areas 1C and 1R) and February 2015 (other areas), three trenches of approximately $30 \times 30 \times$ $40 \mathrm{~cm}$ were opened in each area with a shovel, and the soil was collected at depths of 0-5, 5-10, 10-20, 20-30 and 30$40 \mathrm{~cm}$. Each trench represents a pseudo-replication of the collected area. After collection, the samples were taken to the Laboratório de Análise de Solo, Água e Tecidos Vegetais of the NEPEA-SC (Núcleo de Ensino, Pesquisa e Extensão em Agroecologia) of the Department of Rural Engineering of the Universidade Federal de Santa Catarina (UFSC). Samples were then dried in a forced-air oven at approximately $45^{\circ} \mathrm{C}$, manually ground with a wooden rolling pin, passed through a $2 \mathrm{~mm}$ sieve and reserved for analysis.

\subsection{PHYSICAL AND CHEMICAL ANALYSIS OF THE SOIL}

In the soil samples, particle size analysis was performed according to the Pipette method (EMBRAPA, 1997), and the data is shown in Table 2. In addition, available P contents extracted by Mehlich 1 (Tedesco et al., 1995) were determined by colorimetry (Murphy \& Riley, 1962). Available $\mathrm{Cu}$ and $\mathrm{Zn}$ contents extracted by $0.01 \mathrm{~mol} \mathrm{~L}^{-1} \mathrm{EDTA}$ (Chaignon et al., 2009) were determined by atomic absorption spectrophotometer (AAS). Pseudo-total contents of $\mathrm{Cu}, \mathrm{Zn}, \mathrm{Cd}, \mathrm{Cr}$, Ni and $\mathrm{Pb}$ were obtained from method 3050B proposed by the Environmental Protection Agency (EPA, 1996), which does not dissolve the elements that make up the mineral structure. To this end, we used $1.0 \mathrm{~g}$ of soil from each sample and then added $5 \mathrm{~mL}$ of concentrated $\mathrm{HNO}_{3}$ in digestion tubes, which were placed in a digestion block at $95^{\circ} \mathrm{C}$ for $10 \mathrm{~min}$ and cooled for $15 \mathrm{~min}$. Then, $5 \mathrm{~mL}$ of $\mathrm{HNO}_{3}$ was added and the tubes were again heated to $95{ }^{\circ} \mathrm{C}$ for two more hours. After this period, the samples were cooled for $3 \mathrm{~min}$ and $1 \mathrm{~mL}$ of distilled water and 1.5 $\mathrm{mL}$ of $30 \% \mathrm{H}_{2} \mathrm{O}_{2}$ were added. After effervescence ceased, an additional $5 \mathrm{~mL}$ of $\mathrm{H}_{2} \mathrm{O}_{2}$ was added and the samples were reheated in a digestion block for 2 hours at $95^{\circ} \mathrm{C}$. Finally, the samples were cooled and $10 \mathrm{~mL}$ of concentrated $\mathrm{HCl}$ and $20 \mathrm{~mL}$ of distilled water were added and then heated for $15 \mathrm{~min}$ at $95^{\circ} \mathrm{C}$. The aliquots were cooled, filtered and volume adjusted to $50 \mathrm{~mL}$. $\mathrm{Cu}$ and $\mathrm{Zn}$ contents in extracts were determined by AAS, and $\mathrm{Cd}, \mathrm{Cr}, \mathrm{Ni}$ and $\mathrm{Pb}$ contents in extracts were determined by atomic emission spectrometry (AES).

Table 2: Sand, silt and clay contents in soil of the composting areas and corresponding reference areas.

\begin{tabular}{|c|c|c|c|c|c|c|}
\hline \multirow[t]{3}{*}{ Depth, cm } & Sand & Silt & Clay & Sand & Silt & Clay \\
\hline & \multicolumn{3}{|c|}{$\mathrm{g} \mathrm{kg}^{-1}$} & \multicolumn{3}{|c|}{$\mathrm{g} \mathrm{kg}^{-1}$} \\
\hline & \multicolumn{3}{|c|}{$1 \mathrm{C}$} & \multicolumn{3}{|c|}{$1 \mathrm{R}$} \\
\hline $0-5$ & 805 & 80 & 113 & 651 & 188 & 159 \\
\hline $5-10$ & 626 & 155 & 218 & 736 & 167 & 96 \\
\hline $10-20$ & 575 & 211 & 213 & 741 & 159 & 99 \\
\hline $20-30$ & 591 & 244 & 164 & 638 & 216 & 145 \\
\hline \multirow[t]{2}{*}{$30-40$} & 597 & 179 & 223 & 726 & 117 & 155 \\
\hline & \multicolumn{3}{|c|}{$2 \mathrm{C}$} & \multicolumn{3}{|c|}{$2 \mathrm{R}$} \\
\hline $0-5$ & 593 & 193 & 212 & 495 & 246 & 258 \\
\hline $5-10$ & 599 & 191 & 209 & 334 & 316 & 349 \\
\hline $10-20$ & 619 & 174 & 205 & 225 & 327 & 447 \\
\hline $20-30$ & 570 & 206 & 222 & 174 & 433 & 392 \\
\hline \multirow[t]{2}{*}{$30-40$} & 590 & 205 & 204 & 170 & 390 & 438 \\
\hline & \multicolumn{3}{|c|}{$3 \mathrm{C}$} & \multicolumn{3}{|c|}{$3 \mathrm{R}$} \\
\hline $0-5$ & 695 & 128 & 175 & 505 & 203 & 291 \\
\hline $5-10$ & 638 & 151 & 210 & 469 & 241 & 288 \\
\hline $10-20$ & 574 & 208 & 217 & 424 & 279 & 296 \\
\hline $20-30$ & 681 & 134 & 183 & 464 & 277 & 257 \\
\hline \multirow[t]{2}{*}{$30-40$} & 654 & 177 & 168 & 549 & 259 & 191 \\
\hline & \multicolumn{3}{|c|}{$4 \mathrm{C}$} & \multicolumn{3}{|c|}{$4 \mathrm{R}$} \\
\hline $0-5$ & 482 & 189 & 327 & 638 & 189 & 171 \\
\hline $5-10$ & 428 & 211 & 359 & 570 & 238 & 191 \\
\hline
\end{tabular}


Cleiton Junior Ribeiro Lazzari, Vilmar Müller Junior, Lucas Benedet, Rafael da Rosa Couto, Jucinei José Comin, Arcângelo Loss, Gustavo Brunetto, Paul Richard Momsen Miller, and Cledimar Rogério Lourenzi

\begin{tabular}{|c|c|c|c|c|c|c|c|}
\hline $10-20$ & 403 & 206 & 390 & 615 & 199 & 185 \\
\hline $20-30$ & 495 & 264 & 239 & 693 & 184 & 121 \\
\hline $30-40$ & 498 & 57 & 443 & & 715 & 150 & 134 \\
\hline
\end{tabular}

The contaminant potential of Pin the composting areas was assessed through available P contents. In order to do this, we used parameters obtained by Gatiboni et al. (2015) in which the authors assessed the contaminant potential of $\mathrm{P}$ and established levels for the Environmental Critical Limit of P (ECL-P) in soil. The following equation was used: ECL-P $=40+\%$ of soil clay. Thus, the ECL-P of each area was established using the data obtained in the composting areas. Samples of the organic compost were characterized, and the values are shown in Table 3.

Table 3: Average chemical characteristics of the organic composts produced in the composting piles.

\begin{tabular}{|c|c|c|c|}
\hline Parameter & Value & Parameter & Value \\
\hline $\mathrm{pH}$ & 8.9 & $\mathrm{Na}^{\mathrm{mg} \mathrm{kg}}{ }^{-1}$ & 532.0 \\
\hline Humidity, \% & 32.9 & $\mathrm{Cu}^{\mathrm{mg} \mathrm{kg}}-1$ & 28.4 \\
\hline $\mathrm{TOC}, \%$ & 31.7 & $\mathrm{Zn}^{-1} \mathrm{mg} \mathrm{kg}^{-1}$ & 15.3 \\
\hline $\mathrm{P}, \%$ & 0.86 & $\mathrm{Cd}^{\mathrm{mg} \mathrm{kg}}{ }^{-1}$ & 0.44 \\
\hline $\mathrm{K}, \%$ & 0.9 & $\mathrm{Cr}, \mathrm{mg} \mathrm{kg}^{-1}$ & 3.0 \\
\hline $\mathrm{Ca}, \%$ & 3.4 & $\mathrm{Ni}, \mathrm{mg} \mathrm{kg}^{-1}$ & 1.3 \\
\hline $\mathrm{Mg}, \%$ & 0.4 & $\mathrm{~Pb}, \mathrm{mg} \mathrm{kg}^{-1}$ & 5.0 \\
\hline
\end{tabular}

Values of total $\mathrm{Cd}, \mathrm{Cr}, \mathrm{Ni}$ and $\mathrm{Pb}$ in the compost were taken from Neto (2017).

\subsection{STATISTICAL ANALYSIS}

The data was submitted to analysis of variance (F-test, $p<0.05)$ after testing for homogeneity of variance. To compare the composting areas and corresponding reference areas, the data was evaluated by Student's t-test. The means of the depths were compared by the Scott-Knott test $(\mathrm{p}<0.05)$ within each area. The variables available $P$ $(\mathrm{aP})$, available $\mathrm{Cu}(\mathrm{aCu})$, available $\mathrm{Zn}(\mathrm{aZn})$, total $\mathrm{Cu}(\mathrm{tCu})$, total $\mathrm{Zn}(\mathrm{tZn})$, total $\mathrm{Cr}(\mathrm{tCr})$ and total $\mathrm{Pb}(\mathrm{tPb})$ of all the areas and depths were subjected to Principal Component Analysis (PCA).

\section{RESULTS AND DISCUSSION}

Available $\mathrm{P}$ contents were higher in all the composting areas compared to their corresponding reference areas (Figure 1). The highest available P contents were found at the $0-5 \mathrm{~cm}$ layer. Contents found at this layer were 1200 , 8900, 250 and 3400\% higher in 1C, 2C, 3C and 4C compared to their reference areas, respectively. These results were expected as the literature supports that compost application to soil increases available P contents. In a study in which three soil types were incubated for 330 days with various sources of organic waste, Carmo et al. (2016) found that the application of $10.8 \mathrm{t} \mathrm{ha}^{-1}$ of urban waste compost promoted an increase in soil available $\mathrm{P}$ content compared to the control treatment. In a study carried out in Ireland, Courtney \& Mullen (2008) applied doses of 25, 50 and $100 \mathrm{t} \mathrm{ha}^{-1}$ of spent mushroom compost and found an increase in soil available P contents at all doses. The increase in soil available $\mathrm{P}$ in the composting areas occurs mainly due to $\mathrm{P}$ present in the compost pile that reaches the soil profile, in addition to the presence of organic acids that compete with $\mathrm{P}$ for adsorption sites of soil colloids and favor lower P adsorption, increasing the available P content in soil solution (Pavinato \& Rosolem, 2008).

When $\mathrm{P}$ is added to soil, it tends to accumulate at the surface layers, as it has great affinity with the soil colloids, especially with Fe and Al oxides, hydroxides and oxyhydroxides (Rheinheimer \& Anghinoni, 2001). Natural P contents in soils are typically low. Thus, P added to soil is initially adsorbed to functional groups with an affinity for the element. However, after the saturation of these sites, $\mathrm{P}$ is adsorbed to the less avid sites and therefore with lower binding energy (Barrow et al., 1998). The saturation of the adsorption sites causes $P$ content in the soil solution to increase and results in the migration of P to deeper layers of the soil profile (Lourenzi et al., 2013; Gatiboni et al., 2015).

High available P contents in soil (especially at surface layers) may cause $\mathrm{P}$ to be transferred to water sources. This occurs mainly by surface runoff, where soluble $\mathrm{P}$ and soil particles containing $\mathrm{P}$ are carried by erosion, but also 
by leaching in the profile (Ceretta et al., 2010b; Lourenzi et al., 2014). Therefore, it is important to understand the ability of soils to adsorb $\mathrm{P}$ to colloids without increasing $\mathrm{P}$ concentrations in soil solution. Applying the equation established by Gatiboni et al. (2015) for the composting areas, the ECL-P is 58, 61, 59 and $75 \mathrm{mg} \mathrm{P} \mathrm{dm}^{-3}$ for $1 \mathrm{C}, 2 \mathrm{C}$, 3C and 4C, respectively. Thus, contents in $1 \mathrm{C}$ and $3 \mathrm{C}$ at $0-5 \mathrm{~cm}$ (Figures $1 \mathrm{a}, 3 \mathrm{c}$ ), in 4C up to $10 \mathrm{~cm}$ (Figure 1d) and in 2C at all layers (Figure 1b) were above the ECL-P (range 2), which means that these areas can be sources of environmental pollution to waterbodies. This is even more relevant in coastal areas, where the water table is usually near the soil surface.

Several factors influenced the increase in soil P content in the composting areas. Initially, the contact of the compost pile with the soil added readily available $\mathrm{P}$ and promoted the addition of organic $\mathrm{P}$. With degradation of soil organic matter, organic P can be released in readily available forms to the soil (Vinhal-Freitas et al., 2010). Furthermore, percolated leachate from compost piles may contain total P contents ranging from 4.0 to $20.0 \mathrm{mg} \mathrm{L}^{-1}$ (Mullane et al., 2015), adding significant amounts of $\mathrm{P}$ to soil. Another important factor for the increase in P contents (especially available P) is the increase of $\mathrm{pH}$. As soil $\mathrm{pH}$ increases, there is a reduction in $\mathrm{pH}$-dependent positive charges. Consequently, there is decreased $\mathrm{P}$ adsorption to colloids and increased concentration in soil solution (Sparks, 2003).

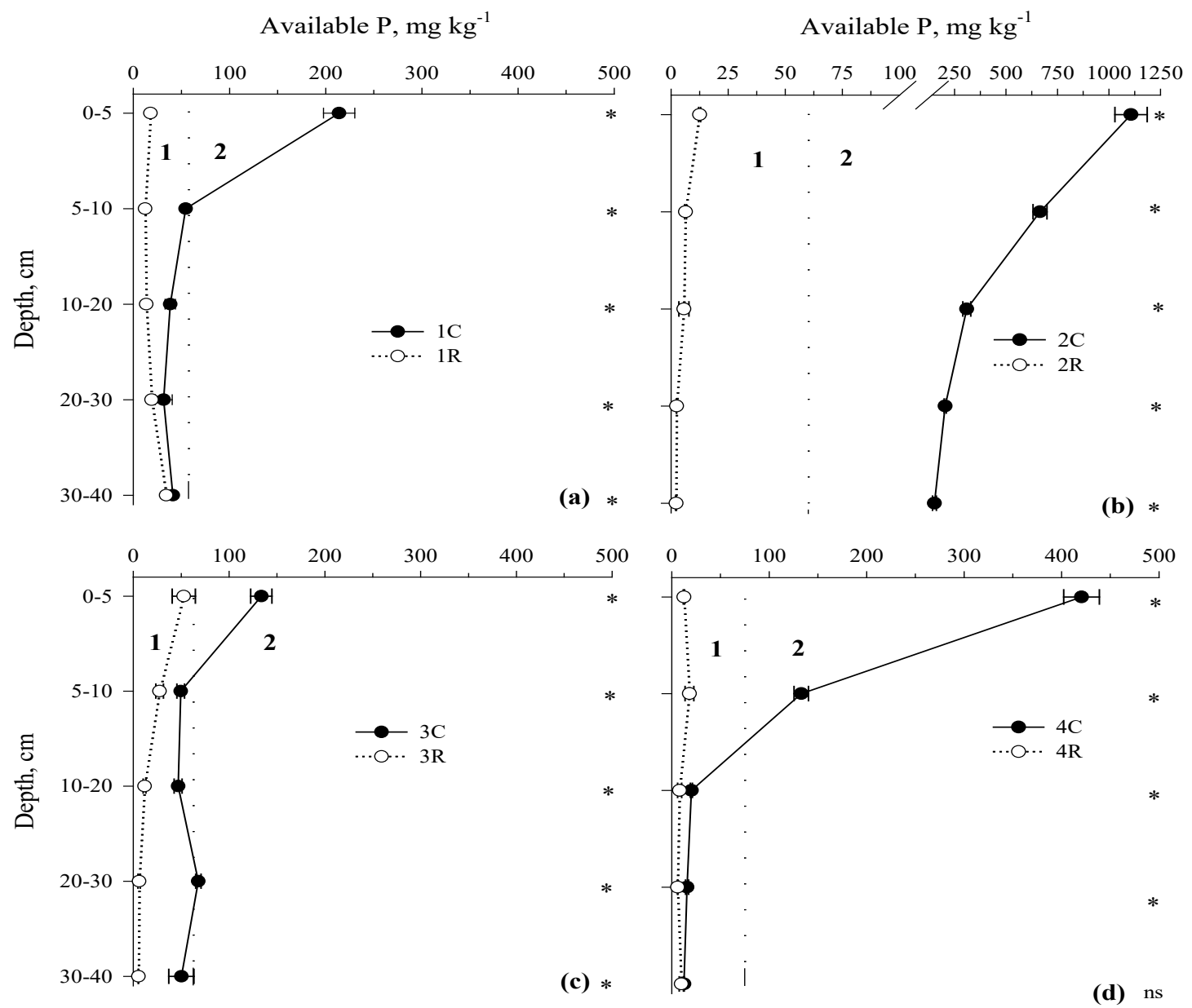

Figure 1: Available phosphorus contents in areas $1 \mathrm{C}$ and $1 \mathrm{R}(\mathrm{a}), 2 \mathrm{C}$ and $2 \mathrm{R}(\mathrm{b}), 3 \mathrm{C}$ and $3 \mathrm{R}(\mathrm{c}), 4 \mathrm{C}$ and $4 \mathrm{R}(\mathrm{d})$. *Significant difference by Student's t-test at 5\%; ns: not significant; 1: Range of soil used as a recycling medium for P; 2: Range of high environmental risk, P content above ECL-P; dashed line represents the ECL-P of each area.

Soil management in the composting areas also favored $\mathrm{P}$ increase. Area $2 \mathrm{C}$ had the highest $\mathrm{P}$ accumulation of all the areas as a result of composting time and because there was no soil scraping in this area. However, soil scraping influenced $\mathrm{P}$ accumulation. In comparing $\mathrm{P}$ contents of the soil layers of the areas, there were higher $\mathrm{P}$ contents in 4C than in $1 \mathrm{C}$ and $3 \mathrm{C}$, which are areas with longer composting time and where soil scraping was used. This trend is 
found up to a depth of $10 \mathrm{~cm}$, after which the contents stabilized. This means that removing the 0-10 $\mathrm{cm}$ layer of topsoil along with the pile also removed the soil that retained most of $\mathrm{P}$ lost by the pile via leachate. Thus, the layer that remains after the removal of the pile had P contents below the ECL-P recommended for this soil. As P is an element with low profile mobility, this technique helps prevent uncovered soil (from which the pile was removed) from containing P contents that could cause environmental problems.

Available $\mathrm{Cu}$ contents were higher in composting areas than in reference areas, except for $2 \mathrm{C}$, where contents were lower than 2R (Figure 2). In the composting areas, we only found the highest available $\mathrm{Cu}$ contents at the surface layer in 4C (Figure 2d), while the highest contents were found at deeper soil layers in the other areas (Figures $2 \mathrm{a}, 2 \mathrm{~b}, 2 \mathrm{c}$ ). In comparing total $\mathrm{Cu}, 1 \mathrm{C}$ had higher contents than the reference area at all layers, while 3C showed higher content only at $0-5 \mathrm{~cm}$. Area $4 \mathrm{C}$ had similar content at $0-5 \mathrm{~cm}$ and higher content up to $20 \mathrm{~cm}$, while $2 \mathrm{C}$ showed total $\mathrm{Cu}$ contents lower than 2R at all layers (Table 4). Available $\mathrm{Zn}$ contents in all composting areas were higher than those found in corresponding reference areas (Figure 3). Similar trend occurred for total Zn contents, except for 1C, which had lower total Zn contents in the reference area up to $10 \mathrm{~cm}$ (Table 5).

Total $\mathrm{Cu}$ values found in all composting areas, except at 20-30 cm in $1 \mathrm{C}$, were lower than those recommended by CONAMA Resolution 420 (Brasil, 2009), which indicates prevention values for total Cu contents in soil of $60 \mathrm{mg}$ $\mathrm{kg}^{-1}$. This resolution uses USEPA method 3050B to determine existing contents in soil samples. Still, according to the same resolution, none of the areas reached the prevention value for $\mathrm{Zn}$, which is $300 \mathrm{mg} \mathrm{kg}^{-1}$ of total $\mathrm{Zn}$ in soil. Composting did not significantly influence $\mathrm{Cu}$ and $\mathrm{Zn}$ contents in the study areas, because of the low contents found in the compost (Table 3). These contents were lower than those found in other composts in literature (Cravo et al., 1998; Ayari et al., 2010; Lourenzi et al., 2016).

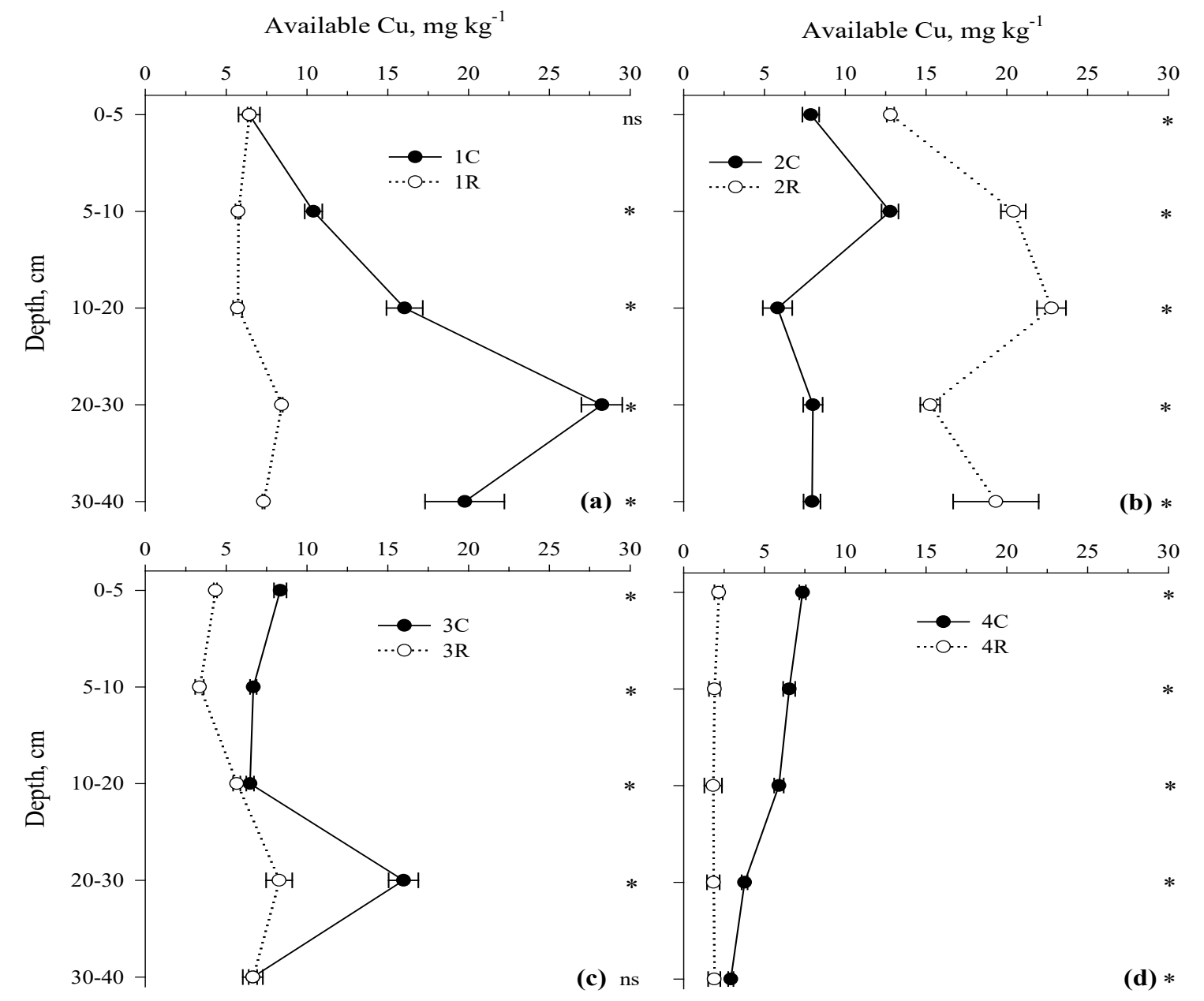

Figure 2: Available $\mathrm{Cu}$ contents in $1 \mathrm{C}$ and $1 \mathrm{R}(\mathrm{a}), 2 \mathrm{C}$ and $2 \mathrm{R}(\mathrm{b}), 3 \mathrm{C}$ and $3 \mathrm{R}(\mathrm{c}), 4 \mathrm{C}$ and $4 \mathrm{R}(\mathrm{d})$. *Significant difference by Student's t-test at 5\%; ns: not significant 
Phosphorus and Heavy Metal Contents in Small-Scale Composting Areas

Table 4: Total $\mathrm{Cu}$ contents in soils of the composting and reference areas.

\begin{tabular}{|c|c|c|c|c|c|c|}
\hline \multirow{2}{*}{$\begin{array}{c}\text { Depth, } \\
\text { cm }\end{array}$} & \multicolumn{7}{|c|}{ Total Cu, mg kg-1 } \\
\cline { 2 - 7 } & $1 \mathrm{C}$ & $1 \mathrm{R}$ & $\mathrm{CV}, \%$ & $2 \mathrm{C}$ & $2 \mathrm{R}$ & $\mathrm{CV}, \%$ \\
\hline $0-5$ & $12.1 \mathrm{c}^{1} \mathrm{~A}^{2}$ & $11.2 \mathrm{aA}$ & 8.39 & $15.6 \mathrm{aB}$ & $37.7 \mathrm{cA}$ & 13.50 \\
\hline $5-10$ & $15.8 \mathrm{bA}$ & $8.3 \mathrm{bB}$ & 2.21 & $13.7 \mathrm{aB}$ & $55.9 \mathrm{bA}$ & 10.35 \\
\hline $10-20$ & $30.3 \mathrm{aA}$ & $7.6 \mathrm{bB}$ & 6.28 & $13.5 \mathrm{aB}$ & $73.7 \mathrm{aA}$ & 5.91 \\
\hline $\mathrm{CV}, \%$ & 3.51 & 8.02 & & 10.14 & 9.12 & \\
\hline $\begin{array}{c}\text { Depth, } \\
\text { cm }\end{array}$ & $3 \mathrm{C}$ & $3 \mathrm{R}$ & $\mathrm{CV}, \%$ & $4 \mathrm{C}$ & $4 \mathrm{R}$ & $\mathrm{CV}, \%$ \\
\hline $0-5$ & $10.7 \mathrm{aA}$ & $6.3 \mathrm{bB}$ & 4.66 & $13.7 \mathrm{cA}$ & $5.0 \mathrm{aA}$ & 26.47 \\
\hline $5-10$ & $7.8 \mathrm{bA}$ & $6.7 \mathrm{bA}$ & 9.37 & $20.7 \mathrm{bA}$ & $4.6 \mathrm{aB}$ & 23.92 \\
\hline $10-20$ & $6.8 \mathrm{bB}$ & $33.7 \mathrm{aA}$ & 12.64 & $29.8 \mathrm{aA}$ & $4.3 \mathrm{aB}$ & 4.24 \\
\hline $\mathrm{CV}, \%$ & 13.04 & 3.85 & & 17.76 & 16.44 & \\
\hline
\end{tabular}

(1) Means followed by the same lowercase letter in the column show no significant differences by the Tukey test ( $<<0.05$ ); (2) Means followed by the same uppercase in the row do not show significant differences by Student's t-test $(\mathrm{p}<0.05)$.

The presence of $\mathrm{Cd}$ and $\mathrm{Ni}$ in soils of the study areas was not detected. Total $\mathrm{Cr}$ contents in $3 \mathrm{C}$ and $4 \mathrm{C}$ were higher than those found in the reference areas (3R and 4R) at all layers. Cr contents in $1 \mathrm{C}$ were higher than in $1 \mathrm{R}$ starting at a depth of $5 \mathrm{~cm}$, while contents in 2C were lower than those found in 2R (Table 6). All composting areas had higher total $\mathrm{Pb}$ contents compared to the reference areas at all layers, except for $1 \mathrm{C}$, which presented contents lower than the reference area at 0-5 cm (Table 7).

Total $\mathrm{Cr}$ contents in the composting areas were below the prevention value described by CONAMA Resolution 420 of 2009 (Brazil, 2009), which is $75 \mathrm{mg} \mathrm{kg}^{-1}$. However, total Pb contents in 3C and 4C were higher than the recommended prevention values $\left(72 \mathrm{mg} \mathrm{kg}^{-1}\right)$ at all layers, and only at $10-20 \mathrm{~cm}$ and $5-10 \mathrm{~cm}$ in $1 \mathrm{C}$ and $2 \mathrm{C}$, respectively. Prevention values indicate the maximum concentration of a given substance in soil in which the soil is still capable of carrying out its main functions, such as serving as a natural filter, as a means for food production, and maintaining the water and nutrient cycle (Brasil, 2009).

However, $\mathrm{Pb}$ contents found may be a result of other factors related to the material deposited in these areas for landfill and not by the compost itself. This is because $\mathrm{Pb}$ contents present in the compost produced in these areas are usually low (Neto, 2017) in comparison to those found in other composts in literature (Cravo et al., 1998; Ayari et al., 2010). Classes for construction waste are established by law (CONAMA, 2002). For instance, classes A (such as bricks, blocks, roof tiles) and B (metal, wood, plastic), which can be reused or recycled, are able to release $\mathrm{Cr}$ and $\mathrm{Pb}$ (De Lima et al., 2008). The use of this type of product mixed with clayey soil (as done in this study) may increase the amount of metals in soil as a result of the release by metals or other debris found in construction waste. Similarly, Baldi et al. (2010) found that there was no significant increase in $\mathrm{Cd}, \mathrm{Cr}, \mathrm{Ni}$ and $\mathrm{Pb}$ contents in soil with the application of different doses of domestic organic waste compost for five years.

The contents of these metals in the final compost are low due to the sorting of organic waste from the other wastes at source. By legislation, urban solid waste includes both organic fraction (e.g. food waste) and inorganic fraction (e.g. mixed dry waste) (Brasil, 2010). Depending on how rigorous sorting at source is, different percentages of contaminated wastes may be found in the material used for composting, increasing the contents of $\mathrm{Cu}, \mathrm{Zn}, \mathrm{Cd}, \mathrm{Cr}$, $\mathrm{Ni}, \mathrm{Pb}$ in the final compost (Richard \& Woodbury, 1992). In a study with compost samples of six Brazilian capitals with different selective collection systems, Cravo et al. (1998) found that $\mathrm{Cu}$ and Zn contents in Florianópolis, Rio de Janeiro and Brasilia were much lower than those found in the other capitals. The sorting of organic waste at source by the residents of Florianópolis began in 1986, and took greater proportions within the city with the implementation of the Beija-Flor Project in 1987. The low contents of heavy metals found by Cravo et al. (1998) prove the effectiveness of sorting organic waste at source. 
Cleiton Junior Ribeiro Lazzari, Vilmar Müller Junior, Lucas Benedet, Rafael da Rosa Couto, Jucinei José Comin, Arcângelo Loss, Gustavo Brunetto, Paul Richard Momsen Miller, and Cledimar Rogério Lourenzi

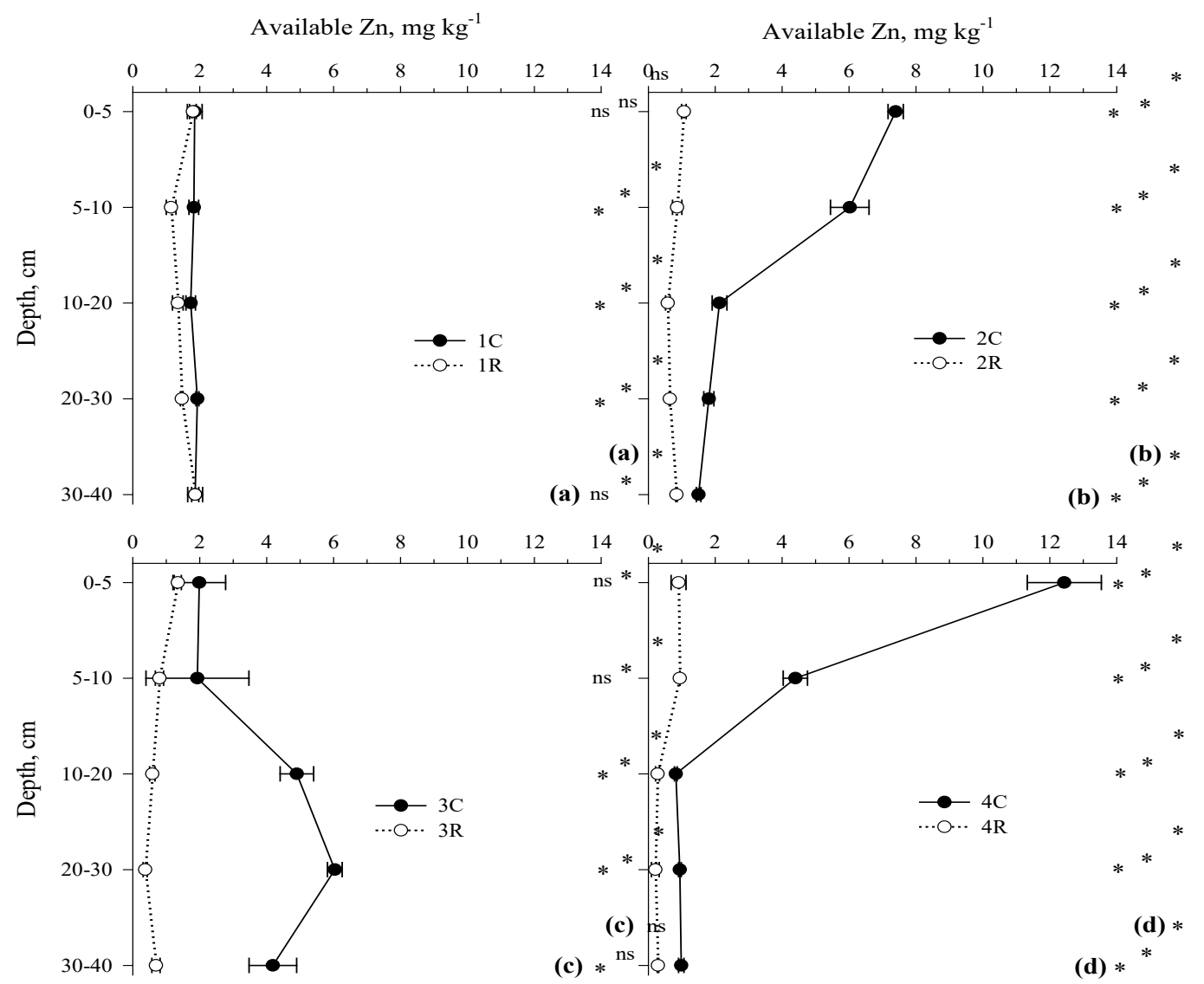

Figure 3: Available Zinc content in 1C and 1R (a), 2C and 2R (b), 3C and 3R (c), 4C and 4R (d). *Significant difference by Student's t-test at 5\%; ns: not significant.

Table 5: Total Zn content in soils of the composting and reference areas.

\begin{tabular}{|c|c|c|c|c|c|c|}
\hline \multirow{2}{*}{$\begin{array}{c}\text { Depth, } \\
\mathrm{Cm}\end{array}$} & \multicolumn{7}{|c|}{ Total Zn, mg kg-1 } \\
\cline { 2 - 7 } & $1 \mathrm{C}$ & $1 \mathrm{R}$ & $\mathrm{CV}, \%$ & $2 \mathrm{C}$ & $2 \mathrm{R}$ & $\mathrm{CV}, \%$ \\
\hline $0-5$ & $13.4 \mathrm{~b}^{1} \mathrm{~B}^{2}$ & $17.9 \mathrm{aA}$ & 11.14 & $38.9 \mathrm{aA}$ & $17.7 \mathrm{aB}$ & 16.83 \\
\hline $5-10$ & $9.6 \mathrm{cB}$ & $15.1 \mathrm{bA}$ & 5.99 & $33.6 \mathrm{aA}$ & $18.0 \mathrm{aB}$ & 6.86 \\
\hline $10-20$ & $16.6 \mathrm{aA}$ & $13.1 \mathrm{bB}$ & 3.47 & $17.9 \mathrm{bA}$ & $17.9 \mathrm{aA}$ & 5.56 \\
\hline $\mathrm{CV}, \%$ & 6.53 & 10.19 & & 15.15 & 4.14 & \\
\hline Depth, cm & $3 \mathrm{C}$ & $3 \mathrm{R}$ & $\mathrm{CV}, \%$ & $4 \mathrm{C}$ & $4 \mathrm{R}$ & $\mathrm{CV}, \%$ \\
\hline $0-5$ & $90.7 \mathrm{aA}$ & $38.4 \mathrm{aB}$ & 1.37 & $38.9 \mathrm{aA}$ & $15.1 \mathrm{bB}$ & 2.88 \\
\hline $5-10$ & $55.6 \mathrm{cA}$ & $34.6 \mathrm{bB}$ & 6.13 & $32.1 \mathrm{bA}$ & $20.3 \mathrm{aB}$ & 6.48 \\
\hline $10-20$ & $77.7 \mathrm{bA}$ & $33.7 \mathrm{bB}$ & 2.25 & $32.1 \mathrm{bA}$ & $12.5 \mathrm{bB}$ & 8.16 \\
\hline $\mathrm{CV}, \%$ & 4.96 & 4.38 & & 5.97 & 12.51 & \\
\hline
\end{tabular}

(1) Means followed by the same lowercase letter in the column show no significant differences by the Tukey test $(\mathrm{p}<0.05)$; (2) Means followed by the same uppercase letter in the row do not show significant differences by Student's t-test $(p<0.05)$.

Table 6: Total $\mathrm{Cr}$ contents in soils of the composting and reference areas.

\begin{tabular}{|c|c|c|c|c|c|c|}
\hline \multirow{2}{*}{$\begin{array}{c}\text { Depth, } \\
\text { cm }\end{array}$} & \multicolumn{7}{|c|}{ Total Cr, mg kg-1 } \\
\cline { 2 - 7 } & $1 \mathrm{C}$ & $1 \mathrm{R}$ & $\mathrm{CV}, \%$ & $2 \mathrm{C}$ & $2 \mathrm{R}$ & $\mathrm{CV}, \%$ \\
\hline $0-5$ & $0.0 \mathrm{c}^{1} \mathrm{~B}^{2}$ & $6.3 \mathrm{aA}$ & 0 & $24.7 \mathrm{aB}$ & $69.7 \mathrm{cA}$ & 3.84 \\
\hline $5-10$ & $8.5 \mathrm{bA}$ & $5.1 \mathrm{aA}$ & 13.03 & $16.2 \mathrm{bB}$ & $124.1 \mathrm{bA}$ & 11.40 \\
\hline $10-20$ & $17.7 \mathrm{aA}$ & $0.0 \mathrm{bB}$ & 6.80 & $11.1 \mathrm{cB}$ & $176.6 \mathrm{aA}$ & 5.72 \\
\hline $\mathrm{CV}, \%$ & 10.82 & 42.24 & & 7.25 & 1.89 & \\
\hline
\end{tabular}


Phosphorus and Heavy Metal Contents in Small-Scale Composting Areas

\begin{tabular}{|c|c|c|c|c|c|c|}
\hline Depth, cm & 3C & 3R & $\mathrm{CV}, \%$ & $4 \mathrm{C}$ & $4 \mathrm{R}$ & $\mathrm{CV}, \%$ \\
\hline $0-5$ & $13.8 \mathrm{bA}$ & $15.01 \mathrm{cB}$ & 18.17 & $35.3 \mathrm{aA}$ & $6.7 \mathrm{cB}$ & 7.64 \\
\hline $5-10$ & $20.1 \mathrm{aA}$ & $4.3 \mathrm{bB}$ & 13.11 & $38.6 \mathrm{aA}$ & $10.6 \mathrm{bB}$ & 3.16 \\
\hline $10-20$ & $8.20 \mathrm{cA}$ & $6.8 \mathrm{aA}$ & 28.06 & $37.0 \mathrm{aA}$ & $12.6 \mathrm{aB}$ & 3.52 \\
\hline $\mathrm{CV}, \%$ & 14.27 & 16.64 & & 5.06 & 6.17 & \\
\hline
\end{tabular}

(1) Means followed by the same lowercase letter in the column show no significant differences by the Tukey test ( $\mathrm{p}<0.05$ ); (2) Means followed by the same uppercase letter in the row do not show significant differences by Student's t-test (p < 0.05).

Table 7: Total soil Pb contents in soils of the composting and reference areas.

\begin{tabular}{|c|c|c|c|c|c|c|}
\hline \multirow{2}{*}{$\begin{array}{c}\text { Depth, } \\
\mathrm{cm}\end{array}$} & \multicolumn{7}{|c|}{ Total Pb, mg kg-1 } \\
\cline { 2 - 7 } & $1 \mathrm{C}$ & $1 \mathrm{R}$ & $\mathrm{CV}, \%$ & $2 \mathrm{C}$ & $2 \mathrm{R}$ & $\mathrm{CV}, \%$ \\
\hline $0-5$ & $15.0 \mathrm{c}^{1} \mathrm{~B}^{2}$ & $81.5 \mathrm{aA}$ & 14.48 & $55.7 \mathrm{aA}$ & $10.8 \mathrm{cB}$ & 27.26 \\
\hline $5-10$ & $71.3 \mathrm{bA}$ & $60.7 \mathrm{bB}$ & 8.77 & $77.6 \mathrm{aA}$ & $19.7 \mathrm{bB}$ & 0.51 \\
\hline $10-20$ & $82.6 \mathrm{aA}$ & $45.0 \mathrm{bB}$ & 6.36 & $63.6 \mathrm{aA}$ & $37.8 \mathrm{aB}$ & 9.36 \\
\hline $\mathrm{CV}, \%$ & 3.01 & 13.49 & & 14.36 & 4.96 & \\
\hline Depth, cm & $3 \mathrm{C}$ & $3 \mathrm{R}$ & $\mathrm{CV}, \%$ & $4 \mathrm{C}$ & $4 \mathrm{R}$ & $\mathrm{CV}, \%$ \\
\hline $0-5$ & $143.0 \mathrm{aA}$ & $62.7 \mathrm{aB}$ & 11.93 & $267.8 \mathrm{aA}$ & $88.77 \mathrm{bB}$ & 3.74 \\
\hline $5-10$ & $89.3 \mathrm{bA}$ & $68.0 \mathrm{aB}$ & 1.51 & $220.6 \mathrm{bA}$ & $175.2 \mathrm{aA}$ & 10.77 \\
\hline $10-20$ & $142.0 \mathrm{aA}$ & $66.1 \mathrm{aB}$ & 0.89 & $193.2 \mathrm{cA}$ & $79.5 \mathrm{bB}$ & 5.73 \\
\hline $\mathrm{CV}, \%$ & 8.28 & 12.08 & & 3.27 & 3.73 & \\
\hline
\end{tabular}

(1) Means followed by the same lowercase letter in the column show no significant differences by the Tukey test (p < 0.05 ); (2) Means followed by the same uppercase letter in the row do not show significant differences by Student's t-test (p < 0.05).

Principal component analysis grouped the variables into 5 components, which explain $97.19 \%$ of the variances (Table 8). PC1 explains $36.64 \%$ of the variances and consists of variables aCu5, aCu10, aCu20, aCu40, tCu5, tCu10, $\mathrm{tCu} 20, \mathrm{tPb} 5, \mathrm{tPb} 10, \mathrm{tCr} 5, \mathrm{tCr} 10$ and $\mathrm{tCr} 20$, with highly significant correlations, as all scores were $\geq 0.5$ (Coelho, 2003). PC2 explains $23.86 \%$ of the variables and, together with CP1, explains $60.5 \%$. This component consists of variables aP5, aP10, aP20, aP30, aP40, aCu5, aCu10, aZn10 and aZn20. PC3, PC4 and PC5 explain 18.53, 13.64 and 4.52\% of the variances, respectively. PC3 is composed of variables aP5, aP10, aZn10, aZn20, aZn30, Zn40, tZn5 and tZn20, while PC4 is composed of aZn5, tPb5, tPb10, tPb20 and tCr5, and CP5 is composed of aCu30.

Through the ordering diagram constructed by PCA (Figure 4), it is possible to notice the formation of 3 distinct groups. One of which is composed by area 2C (related to variables $\mathrm{aP}$ ), another consists of area $2 \mathrm{R}$ (related to variables $\mathrm{aCu}, \mathrm{tCu}$ and $\mathrm{tCr}$ ), and the other areas form a third distinct group (Figure 4). Thus, area 2C stood out from the others due to the high contents of available $\mathrm{P}$, indicating that the area with the longest composting time without soil scraping differed from the other areas. The largest group consisting of areas 1C, 1R, 3C, 3R, 4C and 4R were similar in terms of all the variables assessed in the study. This indicates that the composting time of these areas combined with the use or not of the scraping process did not promote significant differences in the variables. This analysis shows that long-term composting in the same area without scraping the topsoil is more likely to accumulate high $\mathrm{P}$ contents in soil, increasing the chances of environmental problems. The metals assessed in this study, regardless of the composting time or the use of soil scraping, did not increase to levels considered problematic for the environment.

Table 8: Principal component analysis (PCA) of the variables assessed in soil of the composting and reference areas.

\begin{tabular}{|c|c|c|c|c|c|}
\hline Variance Component & CP1 & CP2 & CP3 & CP4 & CP5 \\
\hline Eigenvalue & 9.89 & 6.44 & 5.00 & 3.68 & 1.22 \\
\hline Variability (\%) & 36.64 & 23.86 & 18.52 & 13.64 & 4.52 \\
\hline \% accumulated & 36.64 & 60.50 & 79.03 & 92.67 & 97.19 \\
\hline Variable & \multicolumn{5}{|c|}{ Correlation with principal components } \\
\hline aP51 & -0.31 & $0.78^{*}$ & $-0.52^{*}$ & -0.00 & 0.09 \\
\hline aP10 & -0.29 & $0.76^{*}$ & $-0.54^{*}$ & -0.12 & -0.06 \\
\hline aP20 & -0.28 & $0.78^{*}$ & -0.45 & -0.27 & -0.09 \\
\hline
\end{tabular}


Cleiton Junior Ribeiro Lazzari, Vilmar Müller Junior, Lucas Benedet, Rafael da Rosa Couto, Jucinei José Comin, Arcângelo Loss, Gustavo Brunetto, Paul Richard Momsen Miller, and Cledimar Rogério Lourenzi

\begin{tabular}{|c|c|c|c|c|c|}
\hline aP30 & -0.35 & $0.82^{*}$ & -0.29 & -0.30 & -0.06 \\
\hline aP40 & -0.36 & $0.78^{*}$ & -0.31 & -0.38 & -0.00 \\
\hline aCu5 & $0.66^{*}$ & $0.63^{*}$ & 0.26 & 0.17 & -0.01 \\
\hline aCu10 & $0.79^{*}$ & $0.60^{*}$ & -0.04 & -0.05 & 0.05 \\
\hline aCu20 & $0.91^{*}$ & 0.20 & 0.18 & -0.10 & 0.27 \\
\hline aCu30 & 0.37 & 0.20 & 0.45 & -0.49 & $0.59^{*}$ \\
\hline aCu40 & $0.89^{*}$ & 0.09 & 0.24 & -0.18 & 0.28 \\
\hline aZn5 & -0.29 & 0.43 & -0.38 & $0.67^{*}$ & 0.29 \\
\hline aZn10 & -0.30 & $0.68^{*}$ & $-0.57^{*}$ & 0.23 & 0.21 \\
\hline aZn20 & -0.39 & $0.55^{*}$ & $0.69^{*}$ & -0.19 & 0.05 \\
\hline aZn30 & -0.35 & 0.47 & $0.77^{*}$ & -0.13 & 0.07 \\
\hline aZn40 & -0.32 & 0.43 & $0.77^{*}$ & -0.20 & 0.12 \\
\hline tCu5 & $0.87^{*}$ & 0.41 & 0.01 & 0.16 & -0.09 \\
\hline tCu10 & $0.91^{*}$ & 0.28 & -0.00 & 0.27 & -0.02 \\
\hline tCu20 & $0.90^{*}$ & 0.08 & 0.00 & 0.22 & 0.02 \\
\hline tZn5 & -0.48 & 0.45 & $0.66^{*}$ & 0.19 & -0.21 \\
\hline tZn10 & $-0.51^{*}$ & 0.43 & 0.49 & 0.28 & -0.37 \\
\hline tZn20 & -0.37 & 0.28 & $0.82^{*}$ & 0.22 & -0.12 \\
\hline tPb5 & $-0.51^{*}$ & 0.01 & 0.10 & $0.82^{*}$ & 0.12 \\
\hline tPb10 & $-0.54^{*}$ & -0.24 & -0.23 & $0.65^{*}$ & 0.22 \\
\hline tPb20 & -0.46 & 0.12 & 0.27 & $0.72^{*}$ & 0.39 \\
\hline tCr5 & $0.71^{*}$ & 0.42 & -0.05 & $0.50^{*}$ & -0.21 \\
\hline tCr10 & $0.85^{*}$ & 0.25 & 0.08 & 0.37 & -0.18 \\
\hline tCr20 & $0.92^{*}$ & 0.16 & 0.04 & 0.28 & -0.15 \\
\hline
\end{tabular}

*Variables with higher factor loadings (scores) selected within each component. The criteria for classification were: absolute value $<0.30$, considered slightly significant; 0.30 to 0.49 , moderately significant; and $\geq 0.50$, highly significant according to Coelho (2003). aP: available P; aCu: available $\mathrm{Cu}$; tCu: Total $\mathrm{Cu}$; aZn: available $\mathrm{Zn}$; tZn: Total Zn; tCr: Total Cr; tPb: Total Pb. ${ }^{1}$ Numbers after the abbreviation refer to depths.

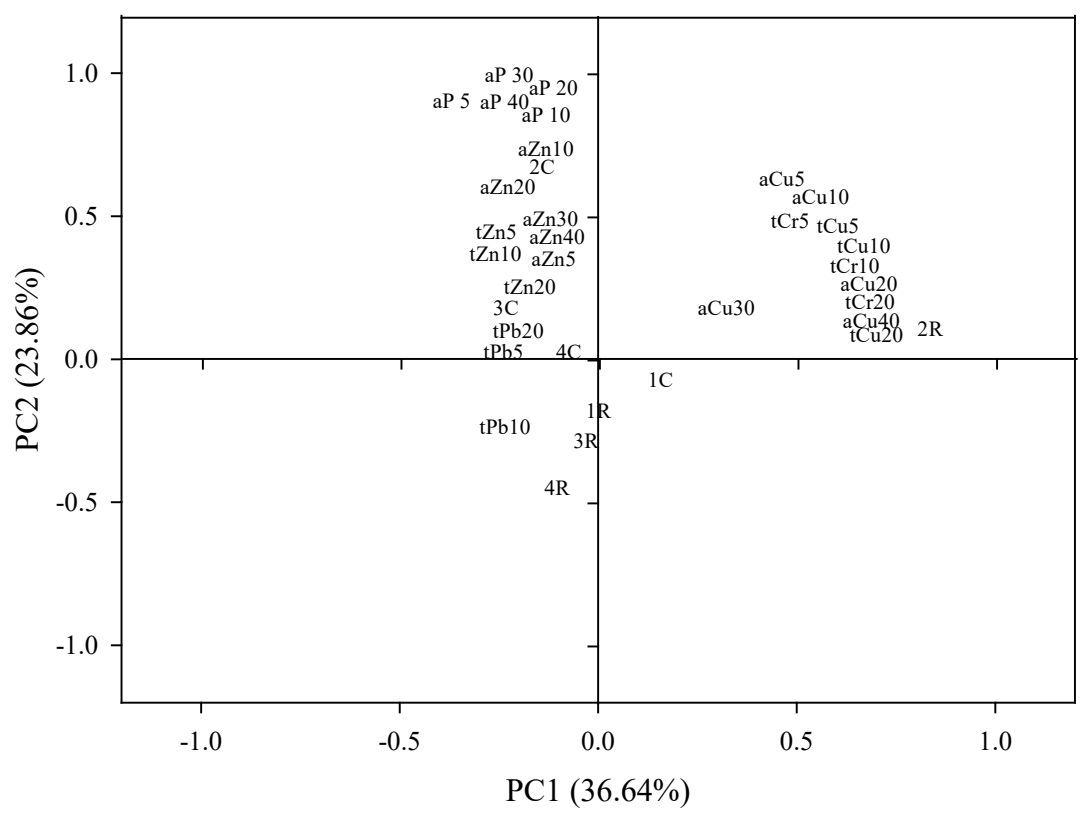

Figure 4: Ordering diagram produced by principal component analysis of the data. aP: available P; aCu: available $\mathrm{Cu}$; tCu: Total $\mathrm{Cu}$; aZn: available Zn; tZn: Total Zn; tCr: Total Cr; tPb: Total Pb; C: composting area, R: reference area. 


\section{CONCLUSION}

The production of small-scale organic compost directly on the soil without weather protection and without soil sealing promoted changes in available $\mathrm{P}, \mathrm{Cu}$ and $\mathrm{Zn}$ contents.

All the areas assessed in this study had P contents above the ECL-P in at least one of the layers, which indicates that composting can increase soil $\mathrm{P}$ above environmentally sound levels.

The presence of $\mathrm{Cu}, \mathrm{Zn}, \mathrm{Cd}, \mathrm{Cr}, \mathrm{Ni}$ and $\mathrm{Pb}$ did not represent an environmental liability in the composting areas. As the compost did not have high contents of these metals, soil contents were kept below the limits recommended by law.

\section{SOURCES OF FUNDING}

This research received no specific grant from any funding agency in the public, commercial, or not-for-profit sectors.

\section{CONFLICT OF INTEREST}

The author have declared that no competing interests exist.

\section{ACKNOWLEDGMENT}

We would like to thank the Coordenação de Aperfeiçoamento de Pessoal de Nível Superior (CAPES) for the financial support to the first author and to the Projeto de Compostagem de Resíduos Urbanos.

\section{REFERENCES}

[1] AYARI, F. et al. Heavy metal distribution in soil and plant in municipal solid waste compost amended plots. Int. J. Environ, v.7, p.465-472, 2010. Doi: 10.1007/bf03326156.

[2] BAGNATI, A. M. Z.; ABREU, J. L. C. Programa beija-flor de tratamento descentralizado de resíduos em Florianópolis-SC, $\quad$ Brasil. 2015.2 Disponível em: <http://portal.pmf.sc.gov.br/arquivos/arquivos/pdf/16_06_2015_14.43.14.ab11ea8a958f79fa0a4a98edfcb d0bdd.pdf>. Acesso em: 15 maio 2019.BALDI, E. et al. Compost can successfully replace mineral fertilizers in the nutrient management of commercial peach orchard. Soil Use and Management, v.26, p.346-353, 2010. Doi:10.1111/j.1475-2743.2010.00286.x.

[3] BARROW, N. J. et al. Effect of previous additions of superphosphate on sorption of phosphate. Soil Research, v.36, p.359-372, 1998.

[4] BERNAL, M. P. et al. Composting of animal manures and chemical criteria for compost maturity assessment. A review. Bioresource Technology, v.100, p.5444-5453, 2009. Doi: 10.1016/j.biortech.2008.11.027.

[5] BRASIL. Conselho Nacional do Meio Ambiente-CONAMA. Resolução № 481, de 03 de Outubro de 2017. Disponível em: <http://www.mma.gov.br/port/conama/res/res17/res48117.pdf>. Acesso em: 26/10/2017.

[6] BRASIL. Conselho Nacional do Meio Ambiente - CONAMA. Resolução № 307, de 05 de Julho de 2002 . № 249. ed. DOU, 30 dez. 2009. p. $\quad 95-96 . \quad$ Disponível em: <http://www.mma.gov.br/estruturas/a3p/_arquivos/36_09102008030504.pdf>.

[7] BRASIL. Conselho Nacional do Meio Ambiente - CONAMA. Resolução № 420, de 28 de Dezembro de 2009. № 249. ed. DOU, 30 dez. 2009. p. 81- 84. Disponível em: < http://www2.mma.gov.br/port/conama/legiabre.cfm?codlegi=620>.

[8] Brasil. Lei no 12.305, de 2 de agosto de 2010. Política Nacional de Resíduos Sólidos, 2010. Disponível em: < http://www.planalto.gov.br/ccivil_03/_Ato2007-2010/2010/Lei/L12305.htm>.

[9] CADIS, P.; HENKES, J. A. Gestão ambiental na suinocultura: sistema de tratamento de resíduos líquidos por unidade de compostagem. Revista Gestão \& Sustentabilidade Ambiental, v. 3, p. 117-142, 2014. Disponível em: < http://portaldeperiodicos.unisul.br/index.php/gestao_ambiental/article/view/2222 > Acessado em: 26/07/2017. Doi: 10.19177/rgsa. v3e12014117-142. 
Cleiton Junior Ribeiro Lazzari, Vilmar Müller Junior, Lucas Benedet, Rafael da Rosa Couto, Jucinei José Comin, Arcângelo Loss, Gustavo Brunetto, Paul Richard Momsen Miller, and Cledimar Rogério Lourenzi

[10] CARMO, D. Soil Fertility and Electrical Conductivity Affected by Organic Waste Rates and Nutrient Inputs. R. Bras. Ciênc. Solo, v. 40, 2016. Doi: 10.1590/18069657rbcs20150152.

[11] CERETTA, C. A. et al. Frações de fósforo no solo após sucessivas aplicações de dejetos de suínos em plantio direto. Pesquisa Agropecuária Brasileira, v.45, p.593-602, 2010a. Doi:10.1590/s0100-204x2010000600009.

[12] CERETTA, C. A. et al. Nutrient transfer by runoff under no tillage in a soil treated with successive applications of pig slurry. Agriculture, Ecosystems \& Environment, v.139, p.689-699, 2010b. Doi: 10.1016/j.agee.2010.10.016.

[13] CHAIGNON, V. et al. Copper availability and bioavailability are controlled by rhizosphere pH in rape grown in an acidic Cu-contaminated soil. Environmental Pollution, v.157, p.3363-3369, 2009. Doi: 10.1016/j.envpol.2009.06.032.

[14] CHATTERJEE N. et al. Chemical and Physical Characteristics of Compost Leachates. A Review. Department of Crop and Soil Sciences: Washington State University; 2013.

[15] CHOWDHURY, A. K. Md. M. B. et al. Olive mill waste composting: A review. International Biodeterioration \& Biodegradation, v.85, p.108-119, 2013. Doi: 10.1016/j.ibiod.2013.06.019.

[16] CHRISTENSEN, T. H. Leaching from land disposed municipal composts: 3. Inorganic ions. Waste Management \& Research, v.2, p.63-74, 1984.

[17] CHRISTENSEN, T. H. \& TJELL, J. C. Leaching from land disposed municipal compost: 4. Heavy metals. Waste Management \& Research, v.2, p.347-357, 1984.

[18] COELHO, A. M. Agricultura de precisão: manejo da variabilidade espacial e temporal dos solos e das culturas. Tópicos em Ciência do Solo. 2003; 3:259-90.

[19] COURTNEY, R. G. \& MULLEN, G.J. Soil quality and barley growth as influenced by the land application of two compost types. Bioresource Technology, v.99, p.2913-2918, 2008. Doi: 10.1016/j.biortech.2007.06.034.

[20] COUTO, R. R. et al. Accumulation and distribution of copper and zinc in soils following the application of pig slurry for three to thirty years in a microwatershed of southern Brazil. Archives of Agronomy and Soil Science, p.1-24, 2015a. Doi:10.1080/03650340.2015.1074183.

[21] COUTO, R. R. et al. Environmental Vulnerability and Phosphorus Fractions of Areas with Pig Slurry Applied to the Soil. Journal of Environment Quality, v. 44, 162-173, 2015b. American Society of Agronomy. Doi:10.2134/jeq2014.08.0359.

[22] CRAVO, M. S. et al. Caracterização química de compostos de lixo urbano de algumas usinas brasileiras. R. Bras. Ciênc. Solo, v. 22, p.547-553, 1998. Doi:10.1590/s0100-06831998000300021.

[23] DAMASCENO, O. I. C. et al. Assessment of bioavailability of heavy metals after vermicomposting in the presence of electronic waste. Revista Brasileira de Ciência do Solo, v. 39, p.1786-1795, 2015. Doi: 10.1590/01000683rbcs20150060.

[24] De Lima et al. Teores de metais pesados em resíduos de construção em Salvador/BA, Brasil. XII Encontro Nacional de Tecnologia do Ambiente Construído - ENTAC, p.1-10, 2008. Disponível em <http://www.infohab.org.br/entac2014/2008/artigos/A2036.pdf>.

[25] EMBRAPA CENTRO NACIONAL DE PESQUISA DE SOLOS. Manual de métodos de análise de solo. 2. ed. Rio de Janeiro: Centro Nacional de Pesquisa de Solos, 1997. 212 p.

[26] EPA - ENVIROMNENTAL PROTECTION AGENCY. Method 3050B. Acid digestion of sediments, sludges, and soils, 1996. <http://www.epa.gov/wastes/hazard/testmethods/sw846/pdfs/3050b.pdf> Acesso em: $25 / 10 / 2015$.

[27] GATIBONI, L. C. et al. Soil phosphorus thresholds in evaluating risk of environmental transfer to surface waters in Santa Catarina, Brazil. R. Bras. Ciênc. Solo, v. 39, n. 4, p.1225-1234, 2015. Doi:10.1590/01000683rbcs20140461.

[28] GUO, Y. \& LI, G. Nitrogen leaching and phosphorus accumulation in a perennial pasture after composted goat manure was topdressed and incorporated in the Three Gorges region. J Soils Sediments, v.12, p.674-682, 2012. Doi:10.1007/s11368-012-0501-5.

[29] HARGREAVES, J. C.; ADL, M.S.; WARMAN, P.R. A review of the use of composted municipal solid waste in agriculture. Agriculture, Ecosystems \& Environment, v.123, p.1-14, 2008. Doi: 10.1016/j.agee.2007.07.004.

[30] INÁCIO, C.T., MILLER, P. R. M. Compostagem: ciência e prática para a gestão de resíduos orgânicos. Rio de Janeiro. Embrapa Solos, 2009. 156p. 


\section{Phosphorus and Heavy Metal Contents in Small-Scale Composting Areas}

[31] JI, Y. et al. Heavy metal accumulation, risk assessment and integrated biomarker responses of local vegetables: A case study along the Le'an river. Chemosphere, v.199, p.361-371, 2018. Doi: 10.1016/j.chemosphere.2018.02.045.

[32] KABATA-PENDIAS, A. \& MUKHERJEE, A. B. Trace elements from soil to human. Springer Science \& Business Media, 2007.561p.

[33] KOPITTKE, P. M. et al. Trace metal phytotoxicity in solution culture: a review. Journal of Experimental Botany, v.61, p.945-954, 2010. Doi:10.1093/jxb/erp385.

[34] LOURENZI, C. R. et al. Atributos químicos de Latossolo após sucessivas aplicações de composto orgânico de dejeto líquido de suínos. Pesq. Agropecu. Bras., v.51, p.233-242, 2016. Doi:10.1590/s0100$204 \times 2016000300005$.

[35] LOURENZI, C. R. et al. Nutrients in soil layers under no-tillage after successive pig slurry applications. R. Bras. Ciênc. Solo, v.37, p.157-167, 2013. Doi:10.1590/s0100-06832013000100016.

[36] LOURENZI, C. R. et al. Pig slurry and nutrient accumulation and dry matter and grain yield in various crops. R. Bras. Ciênc. Solo, v.38, p.949-958, 2014. Doi:10.1590/s0100-06832014000300027.

[37] MAESTRI, J. C. Reciclagem local dos resíduos orgânicos com participação comunitária. 56p. Monografia - Curso de Agronomia, Centro de Ciências Agrárias, Universidade Federal de Santa Catarina, Florianópolis, 2010.

[38] MARTÍNEZ-BLANCO, J. et al. Compost benefits for agriculture evaluated by life cycle assessment. A review. Agronomy for Sustainable Development, v.33, p.721-732, 2013. Doi:10.1007/s13593-013-0148-7.

[39] MULLANE, J. M. et al. Intermittent rainstorms cause pulses of nitrogen, phosphorus, and copper in leachate from compost in bioretention systems. Science of the Total Environment, v.537, p.294-303, 2015. Doi: 10.1016/j.scitotenv.2015.07.157.

[40] MURPHY, J. \& RILEY, J. P. A modified single solution method for the determination of phosphate in natural waters. Analytica Chimica Acta, Oxford, v.27, p. 31-36, 1962.

[41] NETO, R. D. P. Produção de composto em pátio de compostagem municipalutilizando o Método UFSC e análise de sua qualidade química. 88p. Trabalho de Conclusão de Curso - Curso de Agronomia, Centro de Ciências Agrárias, Universidade Federal de Santa Catarina, Florianópolis, 2017.

[42] PAVINATO, P. S. \& ROSOLEM, C. A. Disponibilidade de nutrientes no solo: decomposição e liberação de compostos orgânicos de resíduos vegetais. R. Bras. Ciênc. Solo, v.32, p.911-920, 2008. Doi:10.1590/s010006832008000300001.

[43] RAJESHKUMAR, S. et al. Studies on seasonal pollution of heavy metals in water, sediment, fish and oyster from the Meiliang Bay of Taihu Lake in China. Chemosphere, v.191, p.626-638, 2018. Doi: 10.1016/j.chemosphere.2017.10.078.

[44] RHEINHEIMER, D. S. \& ANGHINONI, I. Distribuição de fósforo inorgânico em sistemas de manejo de solo. Pesq. Agropecu. Bras. v.36, p.151-160, 2001.

[45] RICHARD, T. L. \& WOODBURY, P. B. The impact of separation on heavy metal contaminants in municipal solid waste composts. Biomass and Bioenergy, v.3, p.195-211, 1992. Doi:10.1016/0961-9534(92)90026-M.

[46] SMITH, V. H. et al. Eutrophication of freshwater and marine ecosystems. Limnol. Oceanogr., v.51, p.351-355, 2006. Doi: 10.4319/lo.2006.51.1_part_2.0351.

[47] SPARKS, D. L. Environmental Soil Chemistry. Academic Press, 2 ed. 2003. 352p.

[48] TEDESCO, M. J. et al. Análise de solo, plantas e outros materiais. 2. ed. Porto Alegre: Departamento de Solos, UFRGS, 1995. $174 \mathrm{p}$.

[49] VINHAL-FREITAS, I. C. et al. Microbial and enzymatic activity in soil after organic composting. R. Bras. Ciênc. Solo, v.34, p.757-764, 2010. Doi:10.1590/s0100-06832010000300017. 